\title{
Molecular Identification of Three Argas Species Using Polymerase Chain Reaction (PCR) Amplification and Restriction Analysis of the Small-Subunit Ribosomal RNA Gene
}

\author{
Mohammed H. Awwad, Sahar M. Abou El kheir and Gehan H. Lashien \\ Department of Zoology, Faculty of Science, Zagazig University, Benha Branch
}

\begin{abstract}
The polymerase chain reaction (PCR) and restriction fragment length polymorphisms (RFLPs) of SrRNA gene of Argas species ( 1800 bp) is a very useful technique for differentiation of Argas persicus, Argas hermanni and Argas arboreus species. The PCR/RFLPs profile of EaeI and EcoRI restriction endonucleases were highly characteristic of the genetic interspecific levels and low genetic intraspecific levels of the three species. Other enzymes proved that A. persicus and A. hermanni may be a single or monophyletic species (SacII and SstII restriction endonucleases). AvaII restriction enzyme showed that $A$. hermanni and $A$. arboreus could be a monophyletic species. AvaI restriction endonuclease was the only restriction enzyme to prove that the three Argas species may be polyphyletic species and identified uniquely by this enzyme.
\end{abstract}

\section{Key words: Identification, Argas, RFLPs, SrRNA gene.}

\section{Introduction}

Ticks are beneficial to humans through the direct effects of their feeding and as vectors for various agents of disease in both man and livestock (Sonenshine, 1991; Jongejan and Uilenberg, 1994; Noda et al., 1997 and Cumming, 1998). Tick-transmitted bacterial pathogens are quite diverse and include organisms belonging to the genera Borrelia, Rickettsia, Francisella, Ehrlichia, Anaplasma, Cowdria, and Coxiella (Sonenshine, 1993). Ticks also harbor unidentified nonpathogenic rickettsia- and wolbachia-like bacteria which are possibly mutualistic endosymbionts (Hayes and Burgdorfer, 1981 and Dasch and Weiss, 1992). Numerous reports have been published on the morphological appearance and distribution of symbionts in various tick species (Burgdorfer). Endosymbionts of the soft tick Argas spp. (Persicargas) arboreus (previously thought to be Argas persicus and hereafter referred to as A. arboreus) and the hard tick Dermacentor andersoni have been cultured in the yolk sacs of chicken embryos and found to be pathogenic for guinea pigs (Suitor and Weiss, 1961; Suitor, 1964 and Burgdorfer et al., 1973). The A. arboreus microbe has been placed in the genus Wolbachia and named $W$. persica (Suitor and Weiss, 1961 and Suitor, 1964).

Ticks have traditionally been viewed as relatively host-specific, and it has frequently been assumed that their geographical distributions can be determined by that of their host(s) (Hoogstraal and Aeschlimann, 1982).

In humans, ticks can cause severe toxic conditions such as paralyses and 
toxicoses, irritation and allergy, and their ability to transmit a great variety of infectious diseases is a major public health concern.

Argas spp. transmit a greater variety of pathogenic micro-organisms than any other arthropod vector group (Kohls and Hoogstraal, 1961; Filippova, 1966; Fedorov, 1968; Grzywacz and Kuzmicki, 1975; Keirans et al., 1979; Miadonna et al., 1982; Schwan et al., 1992 and Estrada-Pena and Jongejan, 1999). Argas spp. is usually associated with bats, although Hoogstraal (1956) identified it as a human parasite in Egypt.

The importance of ticks in the natural history of West Nile virus is unknown (Hoogstraal, 1985). The isolation of West Nile virus from A. hermanni infesting pigeon houses in Egypt during winter suggests that this species could serve as a host for the virus during winter (Schmidt and Said, 1964).

Argas spp. is wide distributed in Egypt and threatened our poultry evolution and human health. Many clinical signs and pathogenicity appe ared among animals. Infections with Argas spp. may cause ruffled feathers, poor appetite (anorexia), diarrhea, emaciation and lowered production. Heavy infections with Argas spp. can cause loss of blood leading to anaemia and eventually death (Jongejan, 1999).

Identification of genotype of ticks would be a key to control it. So, in this research it has been attempted to accomplish two main goals. First, complete detection of the nuclear small ribosomal subunit RNA genes have been used in RFLPS analysis to study phylogenetic relationships among three Argas species (A. persicus, A. hermanni and $A$. arboreus). The purpose was to discover whether the three species are a valid monophyletic group or whether the three species are more likely polyp- hyletic. The second goal was to find some specific restriction endonucleases to identify individual species.

\section{Material And Methods}

Arthropods. Three species of soft tick Argas, family Argasidae, were collected from three different birds (Argas persicus from chicken; Argas hermanni from pigeon and Argas arboreus from heron). These ticks were transferred to the laboratory of Faculty of Science, Zagazig University, Benha branch.

DNA preparation and PCR amplification. DNA genome was extracted from the three Argas spp. by homogenizing them in UNSET lysis solution (Hugo et al., 1992 and Awwad and Morsy, 2001). One $\mu 1$ of the DNA was checked by $0.8 \%$ agarose gel electrophoresis for the presence of DNA, as in Figure 1.

To amplify the complete nuclear SrRNA gene, one $\mu$ l of whole-cell DNA template was used plus oligonucleotide primers complementary either to the 5 and 3 ends of the gene (ssu1 and ssu2). The standard PCR reaction mixture was used (Kessing et al., 1989). The entire nuclear SrDNA was amplified using the primers SSU1 (5'-CGACTGGTTGATC CTGCCAGTAG-3') and SSU2 (3'TCCTGATCCTTCTCAGGTTCAC-5') anchored respectively in the conserved extremities of the $18 \mathrm{~S}$ ribosomal gene (Stohard and Rollinson, 1997). The standard polymerase chain reaction program for amplification of nuclear SrRNA was: $30-35$ cycles; one minute, at $94^{\circ} \mathrm{C}$; two to three minutes, at $45^{\circ} \mathrm{C}$; and three minutes, at $72^{\circ} \mathrm{C}$.

PCRIRFLPs of rDNA. The enzymes were tested including EaeI (Roche Applied Science), EcoRI, AvaI, SstII (Sigma-Aldrich) and SacII, AvaII (Boehringer Mannheim) to distinguish the rDNA gene of the three Argas 
species. One microlitre (10-12 units) was used for each digestion reaction, together with $1.2 \mu 1$ of the respective enzyme buffer for a final volume of $12.2 \mu \mathrm{l}$. The digestion was performed for $\sim 3.5 \mathrm{~h}$ at $\sim 37^{\circ} \mathrm{C}$, and the digestion products were evaluated on $2 \%$ TBEagarose gels and stained with ethidium bromide. Bands were detected upon ultraviolet transillumination and photographed (Awwad and Morsy, 2001).

\section{Results}

Complete nuclear SrRNA genes (SrDNA) were obtained for the three Argas strains from the PCR products. The sizes of the nuclear SrDNA genes were approximately 1800 bp (Figure 2).

EaeI and EcoRI restriction endonucleases did not differentiate the three Argas species (Figures 3 and 4; Tables 1 and 2). EaeI restriction enzyme digested the PCR product (SrDNA) of the three Argas species (A. persicus, A. hermanni and $A$. arboreus) into three restriction patterns $(\sim 300, \sim 500$ and $\sim 1000$ bp, lanes 1-3; Figure 3; Table 1), whenever EcoRI restriction endonuclease fragmented the same gene of the three species into two restriction bands ( $\sim 250$ and $\sim 1550 \mathrm{pb}$, lanes 1-3; Figure 4; Table 2).

A. persicus and A. hermanni were remained undifferentiated when their SrRNA gene digested with SacII and SstII restriction endonucleases, but the same restriction enzymes differentiated A. arboreus when compared to the other two species (Figures 5 and 6; Tables 3 and 4). SacII restriction enzyme cut the PCR product of $A$. percicus and $A$. hermanni into two restriction fragments ( 550 and $\sim 1250 \mathrm{bp}$, lanes 1 and 2; Figure 5; Table 3) and digested the gene of $A$. arboreus into three restriction patterns ( 200, 400 and $\sim 1200 \mathrm{bp}$, lane 3; Figure 5; Table 3). Also, SstII restriction enzyme digested the nuclear gene of $A$. persicus and $A$. hermanni into two restriction bands $(\sim 500$ and $\sim 1300$ bp, lanes 1 and 2; Figure 6; Table 4) and $A$. arboreus into three restriction patterns $(\sim 300, \sim 600$ and $\sim 900 \mathrm{bp}$, lane 3; Figure 6; Table 4).

AvaII restriction enzyme did not differentiate between A. hermanni and $A$. arboreus, but differentiated between these two species and A. persicus (Figure 7 and Table 5). The restriction enzyme, AvaII digested the SrRNA gene of $A$. persicus into five restriction fragments $(\sim 50, \sim 150, \sim 300, \sim 600$ and $\sim 700 \mathrm{bp}$, lane 1; Figure 7 and Table 5). Simultaneously, the same restriction enzyme digested the gene of $A$. hermanni and $A$. arboreus into five restriction fragments but different than the RFLP profile of $A$. persicus in sizes $(\sim 150, \sim 200, \sim 250, \sim 450$ and $\sim 750 \mathrm{bp}$, lanes 2 and 3; Figure 7 and Table 5).

AvaI restriction endonuclease differentiated between the three Argas species (Figure 8 and Table 6). AvaI restriction enzyme did not react with the gene of $A$. persicus (lane 1; Figure 8 and Table 6). The same restriction enzyme digested the SrDNA of $A$. hermanni into two restriction bands ( 200 and $\sim 1600$ bp, lane 2; Figure 8 and Table 6) and gave three restriction patterns with $A$. arboreus ( 200, 300 and $\sim 1300$ bp, lane 3; Figure 8 and Table 6). 
Table 1: Shows the length of SrRNA genes fragments, resulted from digestion with EaeI enzyme in the three Argas species.

\begin{tabular}{|l|l|l|l|l|l|}
\hline Argas strain & Band 1 & Band 2 & Band 3 & Band 4 & Band 5 \\
\hline A. persicus & $\sim 300$ & $\sim 500$ & $\sim 1000$ & ------ & ------ \\
\hline A. hermanni & $\sim 300$ & $\sim 500$ & $\sim 1000$ & ----- & ----- \\
\hline A. arboreus & $\sim 300$ & $\sim 500$ & $\sim 1000$ & ------ & ----- \\
\hline
\end{tabular}

Table 2: Shows the length of SrRNA genes fragments, resulted from digestion with EcoRI enzyme in the three Argas species.

\begin{tabular}{|l|l|l|l|l|l|}
\hline Argas strain & Band 1 & Band 2 & Band 3 & Band 4 & Band 5 \\
\hline A. persicus & $\sim 250$ & $\sim 1550$ & ------ & ------ & ------ \\
\hline A. hermanni & $\sim 250$ & $\sim 1550$ & ----- & ----- & ----- \\
\hline A. arboreus & $\sim 250$ & $\sim 1550$ & ------ & ----- & ----- \\
\hline
\end{tabular}

Table 3: Shows the length of SrRNA genes fragments, resulted from digestion with SacII enzyme in the three Argas species.

\begin{tabular}{|l|l|l|l|l|l|}
\hline Argas strain & Band 1 & Band 2 & Band 3 & Band 4 & Band 5 \\
\hline A. persicus & $\sim 550$ & $\sim 1250$ & ------ & ------ & ------ \\
\hline A. hermanni & $\sim 550$ & $\sim 1250$ & ----- & ----- & ----- \\
\hline A. arboreus & $\sim 200$ & $\sim 400$ & $\sim 1200$ & ------ & ------ \\
\hline
\end{tabular}

Table 4: Shows the length of SrRNA genes fragments, resulted from digestion with Sst II enzyme in the three Argas species.

\begin{tabular}{|l|l|l|l|l|l|}
\hline Argas strain & Band 1 & Band 2 & Band 3 & Band 4 & Band 5 \\
\hline A. persicus & $\sim 500$ & $\sim 1300$ & ------ & ------ & ------ \\
\hline A. hermanni & $\sim 500$ & $\sim 1300$ & ----- & ----- & ----- \\
\hline A. arboreus & $\sim 300$ & $\sim 600$ & $\sim 900$ & ----- & ----- \\
\hline
\end{tabular}

Table 5: Shows the length of SrRNA genes fragments, resulted from digestion with AvaII enzyme in the three Argas species.

\begin{tabular}{|l|l|l|l|l|l|}
\hline Argas strain & Band 1 & Band 2 & Band 3 & Band 4 & Band 5 \\
\hline A. persicus & $\sim 50$ & $\sim 150$ & $\sim 300$ & $\sim 600$ & $\sim 700$ \\
\hline A. hermanni & $\sim 150$ & $\sim 200$ & $\sim 250$ & $\sim 450$ & $\sim 750$ \\
\hline A. arboreus & $\sim 150$ & $\sim 200$ & $\sim 250$ & $\sim 450$ & $\sim 750$ \\
\hline
\end{tabular}

Table 6: Shows the length of SrRNA genes fragments, resulted from digestion with AvaI enzyme in the three Argas species.

\begin{tabular}{|l|l|l|l|l|l|}
\hline Argas strain & Band 1 & Band 2 & Band 3 & Band 4 & Band 5 \\
\hline A. persicus & $\sim 1800$ & ----- & ----- & ----- & ----- \\
\hline A. hermanni & $\sim 200$ & $\sim 1600$ & ----- & ----- & ----- \\
\hline A. arboreus & $\sim 200$ & $\sim 300$ & $\sim 1300$ & ------ & ----- \\
\hline
\end{tabular}



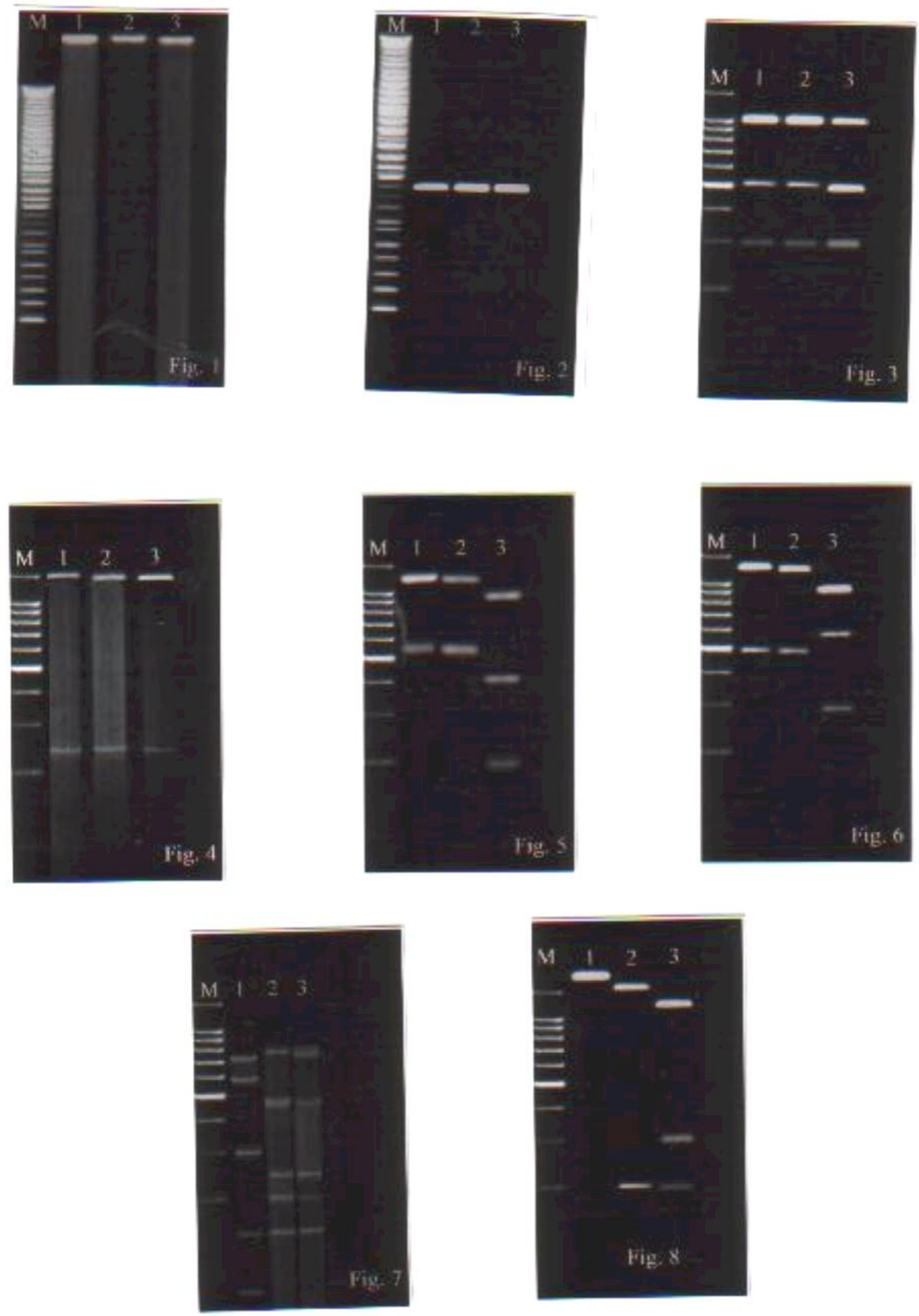
Figure 1: Total DNA genome from Argas sp. Lane $\mathrm{M}$ is DNA marker. Lanes 1, 2 and 3 represent the chromosomal DNA of Argas persicus, Argas hermanni and Argas arboreus respectively.

Figure 2: Shows full-segment SrRNA gene ( 1800 bp) of Argas sp. Lane M is the DNA marker. Lanes 1, 2 and 3 represent SrDNA of Argas persicus, Argas hermanni and Argas arboreus respectively.

Figure 3: Shows the representative SrDNA PCR/RFLPs bands from Argas persicus (lane 1), Argas hermanni (lane 2) and Argas arboreus (lane 3) with EaeI restriction endonuclease, which produced roughly the same fragments (three bands: $\sim 300, \sim 500$ and $\sim 1000 \mathrm{bp}$, for all). Lane $\mathrm{M}$ is the DNA marker.

Figure 4: Shows the representative SrDNA PCR/RFLPs patterns from Argas persicus (lane1), Argas hermanni (lane 2) and Argas arboreus (lane 3) with EcoRI restriction endonuclease, which produced roughly the same fragments (two bands: $\sim 250$ and $\sim 1550$ $\mathrm{bp}$, for all). Lane $\mathrm{M}$ is the DNA marker.

Figure 5: Shows SacII restriction enzyme digested the SrRNA gene of Argas persicus and Argas hemanni roughly the same fragments (two bands: $\sim 550$ and $\sim 1250 \mathrm{bp}$; lanes 1 and 2), and the SrRNA gene of Argas arboreus into three fragments $(\sim 200, \sim 400$ and $\sim 1200$ bp; lane 3). M lane is the DNA marker.

Figure 6: Shows SstII restriction enzyme digested the SrRNA gene of Argas persicus and Argas hemanni roughly the same fragments (two bands: $\sim 500$ and $1300 \mathrm{bp}$; lanes 1 and 2), and the SrRNA gene of Argas arboreus into three fragments $(\sim 300, \sim 600$ and $\sim 900$ bp; lane 3). M lane is the DNA marker.

Figure 7: Shows the representative SrDNA PCR/RFLPs patterns of AvaII enzyme of Argas hermanni (lane 2) and Argas arboreus (lane 3) producing roughly the same patterns (five bands: $\sim 150, \sim 200, \sim 250, \sim 450$ and $\sim 750 \mathrm{bp}$ ) and the same gene of Argas persicus (lane 1) into five different sized bands $(\sim 50, \sim 150, \sim 300, \sim 600$ and $\sim 700 \mathrm{bp})$. $\mathrm{M}$ lane is the DNA marker.

Figure 8: Shows AvaI restriction enzyme did not react with the gene of Argas persicus (lane 1), digested the SrDNA of Argas hermanni into two restriction bands ( 200 and $\sim 1600 \mathrm{bp})$ and gave three restriction patterns with Argas arboreus ( 200, 300 and $\sim 1300$ bp). M lane is the DNA marker.

\section{Discussion}

In this study it has been attempted to achieve a target, to resolve whether A. persicus, A. hermanni and $A$. arboreus are a single species (monophyletic relationship) or the three species are not related to each other (polyphyletic relationship) and/or if any of them are related to another each other. The objective is very valuable to determine because $A$. persicus, A. hermanni and $A$. arboreus transmit a greater variety of pathogenic micro-organisms than any other arthropod vector group to animals and humans and there have been many complexities with classification of pathogenic carrier Argas species in the past. (Kohls and Hoogstraal, 1961; Filippova, 1966; Fedorov, 1968; Grzywacz and Kuzmicki, 1975; Keirans et al., 1979; Miadonna et al., 1982; Schwan et al., 1992 and Estrada-Pena and Jongejan, 1999). Polymerase chain reaction/re-striction fragment length polymor-phisms(PCR/RFLPs) of smallsubunit ribosomal RNA gene is a modern molecular biological technique by which, the problem of unclear relationship between $A$. persicus, A. hermanni and $A$. arboreus could be resolved.

A. persicus, A. hermanni and A. arboreus remained undifferentiated when their SrRNA gene digested with 
EaeI and EcoRI restriction endonucleases and gave the same PCR/RFLPs profiles (Figures 3 and 4). This indicated that $A$. persicus, A. hermanni and $A$. arboreus species may be a single, or monophyletic species.

SacII and SstII restriction endonucleases proved that $A$. persicus and $A$. hermanni may be one species or monophyletic and $A$. arboreus is polyphyletic when related to the other two species or different species. SrRNA gene PCR/RFLPs of SacII and SstII restriction enzymes of $A$. persicus and $A$. hermanni gave the same profiles and gave a different profile with $A$. arboreus (Figure 5 and 6).

On the other hand, AvaII restriction enzyme showed similarity between $A$. hermanni and A. arboreus species and dissimilarity between these two species and $A$. persicus species. SrDNA PCR/RFLPs of AvaII restriction endonuclease gave same profile with $A$. hermanni and $A$. arboreus species and different profile with $A$. persicus species when compared to the others. This indicated that $A$. persicus species may be different or polyphyletic species when compared to the single or monophyletic $A$. hermanni and $A$. arboreus species. AvaI restriction endonuclease was a different and more specific enzyme than the other restriction enzymes used in this work. This enzyme gave a different and specific PCR/RFLPs profile with each one of the three Argas species. $A v a \mathrm{I}$ restriction enzyme did not digest the gene of $A$. persicus, digested the gene of $A$. hermanni into two bands and digested SrDNA of $A$. arboreus into three restriction fragments. AvaI restriction endonuclease proved that $A$. persicus, A. hermanni and A. arboreus may be all polyphyletic or in a different manner they are different species.

From examination of restriction enzyme analysis of SrRNA gene, it is believed that $A$. persicus, A. hermanni and $A$. arboreus may be monophyletic species and related to the same species with some minor differences. These differences could extend to differentiate the three species as a different and polyphyletic species with some exception. $A$. persicus and $A$. hermanni are related to each other, while, A. hermanni and $A$. arboreus are close enough to each other, A. persicus and A. arboreus are not related. It appears also that PCR/ RFLPs of nuclear SrDNA generated by restriction endonuclease could be used for preliminary characterization of this species complex.

\section{References}

1. Awwad, M.H. and Morsy, G.H. (2001): Small subunit ribosomal RNA gene identification of the human pathogen Schistosoma sp. in Egypt. Egypt. J. Aquat. Biol. Fish. 5(4): 281294.

2. Burgdorfer, W.; Brinto, L.P. and Hughes, L.E. (1973): Isolation and characterization of symbiotes from the Rocky Mountain wood tick, Dermacentor andersoni. J. Invertebr. Pathol. 22:424-434.

3. Cumming, G.S. (1998): Host preference in African ticks (Acari: Ixodida): a quantitative data set. Bull. Entomol. Res. 88: 379-406.

4. Dasch, G.A.; and Weiss, E. (1992): The genera Rickettsia, Rochalimaea, Ehrlichia, Cowdria, and Neorickettsia, 2407-2470. In A. Balows, H. G. Trüper, M. Dworkin, W. Harder, and K.-H. Schleifer (ed.), The prokaryotes, vol. 3. Springer-Verlag, New York, N.Y.

5. Estrada-Pena, A. and Jongejan, F. (1999): Ticks feeding on humans: a review of records on human-biting Ixodoidea with special reference to pathogen transmission. Exp. App. Acarol. 23: 685-715.

6. Fedorov, V.G. (1968): Ixodoidea ticks on humans in western Siberia. Medits. Parazitol., Moscow. 37: 615-615. 
7. Filippova, N. (1966): Argasid ticks (Argasidae). Fauna SSSR, Paukoobraznye. 4: 1-255.

8. Grzywacz, M. and Kuzmicki, R. (1975): A case of Argas reflexus (Fabricius) attack on man. Wiado. Lekarskie. 28: 1571-1577.

9. Hayes, S.F. and Burgdorfer, W. (1981): Ultrastructural comparisons of Wolbachia-like symbiotes of ticks (Acari: Ixodidae), 281-289. In W. Burgdorfer and R. L. Anacker (ed.), Rickettsiae and rickettsial diseases. Academic Press, New York, N.Y.

10. Hoogstraal, H. and Aeschlimann, A. (1982): Tick-host specificity. Bull. Soc. Entomol. Suisse. 55: 5-32.

11. Hoogstraal, H. (1956): African Ixodoidea. I. Ticks of the Sudan (with special reference to Equatoria province and with preliminary reviews of the genera Boophilus, Margaropus, and Hyalomma. Dept. of the Navy, Bureau of Medicine and Surgery, Washington, D.C.

12. Hoogstraal, H. (1985): Argasid and Nuttallielid ticks as parasites and vectors. Adv. Parasitol. 24: 136-220.

13. Hugo, E.R.; Stewart, V.J.; Gast, R.J.; Byers, T.J. (1992). Purification of amoeba mtDNA using the UNSET procedure. In "Protocols in Protozoology," J.J. Lee \& A.T. Soldo, eds, Soc. Protozoologists, Lawrence, KA. pp D7.1-D7.2.

14. Jongejan, F. and Uilenberg, G. (1994): Ticks and Control Methods. Rev. Sci. Tech. Off. Int. Epiz. 13(4): 1201-1226.

15. Keirans, J.E.; Hoogstraal, H. and Clifford, C.M. (1979): Observations on the subgenus Argas (Ixodoidea: Argasidae: Argas). 16 Argas (A.) moreli, new species, and keys to Neotropical species of the subgenus. J. Med. Entomol. 15: 246-252.

16. Kessing, B.; Croom, H.; Martin, A.; McIntosh, C.; McMillan, W.O. and Palumbi, S. (1989). The Simple Fool's Guild to PCR (S. Palumbi And C. Simon lab manual).

17. Kohls, G.M. and Hoogstraal, H. (1961): Observations on the subgenus
Argas (Ixodoidea, Argasidae, Argas). 4. A. neghmei, new species, from poultry houses and human habitations in northern Chile. Annals Ent. Soc. Amer. 54: 844-851.

18. Miadonna, A.; Tedeschi, A.; Leggieri, E.; Falagiani, P.; Nazzari, M.; Manzoni, M. and Zanussi, C. (1982): Anaphylactic shock caused by allergy to the venom of Argas reflexus. Ann. Aller. 49: 239-295.

19. Noda, H.; Munderloh, U.G. and Kurtti, T.J. (1997): Endosymbionts of Ticks and Their Relationship to Wolbachia spp. and Tick-Borne Pathogens of Humans and Animals. App. Envir. Microbiol. 63(10): 39263932.

20. Schmidt, J.R. and Said, M.I. (1964): Isolation of West Nile virus from the African bird argasid, Argas reflexus hermanni, in Egypt. J. Med. Entomol. 1: 83-86.

21. Schwan, T.G.; Corwin, M.D. and Brown, S.J. (1992): Argas (Argas) monolakensis, new species (Acari: Ixodoidea: Argasidae), a parasite of California gulls on islands in Mono Lake, California: description, biology, and life cycle. J. Med. Entomol. 29: 78-97.

22. Sonenshine, D.E. (1991): Biology of ticks. Vol. 1, Oxford University Press, Oxford.

23. Sonenshine, D.E. (1993): Biology of ticks, vol. 2. Oxford University Press, Oxford.

24. Stohard, J.R.; Rollinson, D. (1997). Molecular characterization of Bulinus globosus and B. nasutus on Zanzibar, and an investigation of their roles in the epidemiology of Schistosoma haematobium. Trans. R. Soc. Trop. Med. Hyg. 91: 353-357.

25. Suitor, E.C. (1964): The relationship of Wolbachia persica Suitor and Weiss to its host. J. Insect Pathol. 6:111-124.

26. Suitor, E.C., and Weiss, E. (1961): Isolation of a rickettsialike microorganism (Wolbachia persica, n. sp.) from Argas persicus (Oken). J. Infect. Dis. 108: 95-106. 


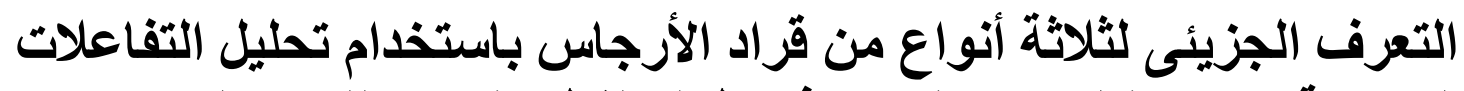

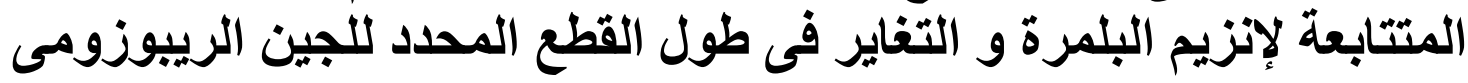

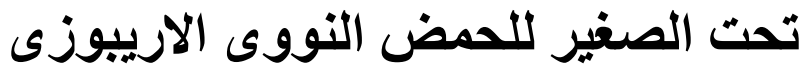

\author{
محمد حسين عواد, سحر محمد أبو الخير وجيهان حسين لاثين

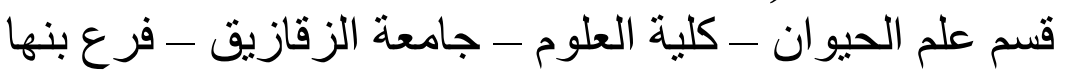

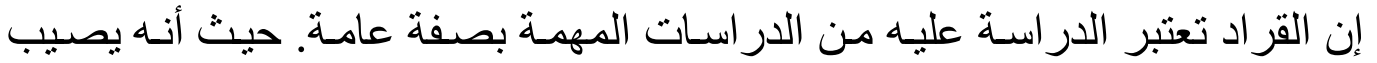

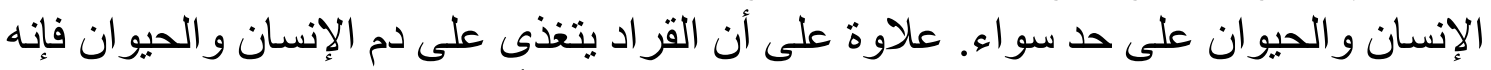

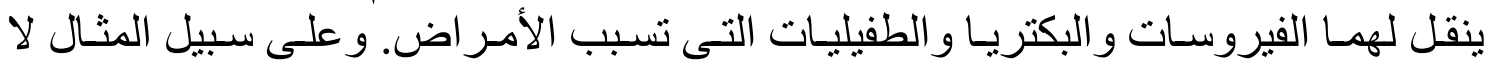

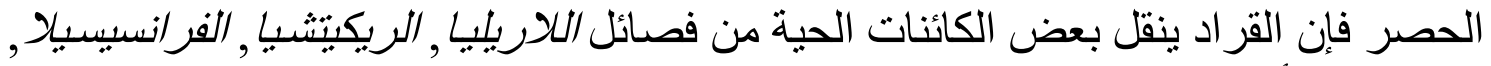

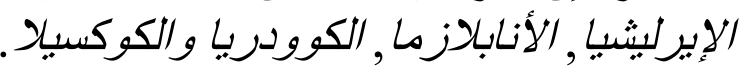

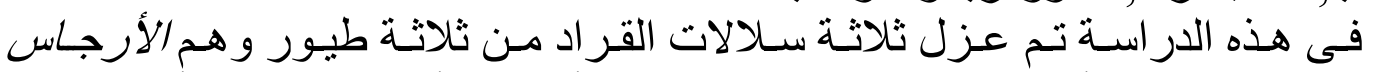

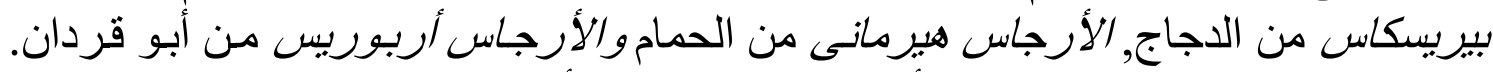

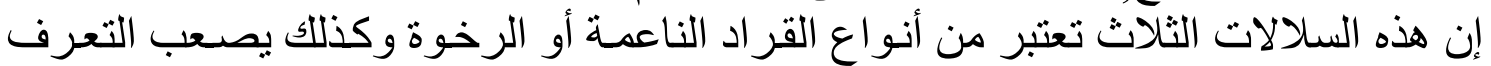

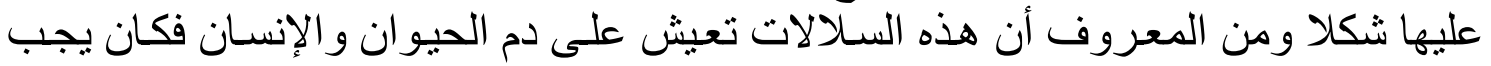

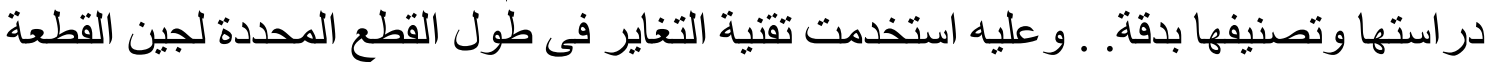

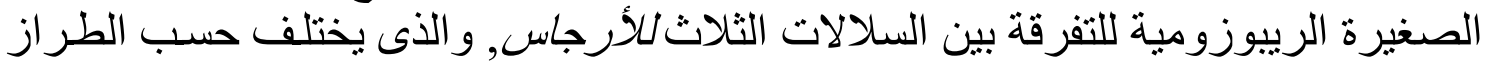
الذى بنتمى اليه الكائن الحى. وقد تم عن طريق الفرد أو الفصل الكهربى استخلاص جينـات الجسم الريبوزى من التن

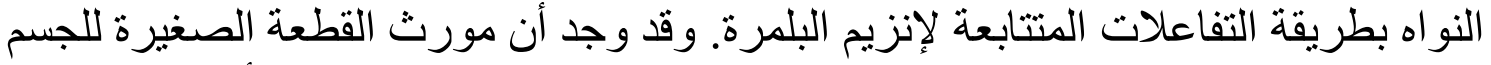

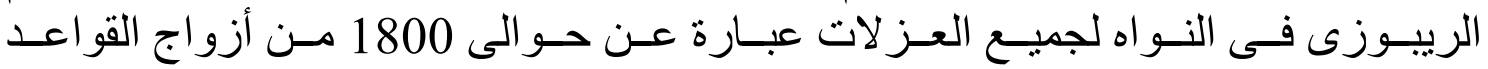
النبتروجينية. وقد وجد أنه عند هضم الجين بإنزيمى EaeI و EcoRI أن سلالات جنس الأرجاس

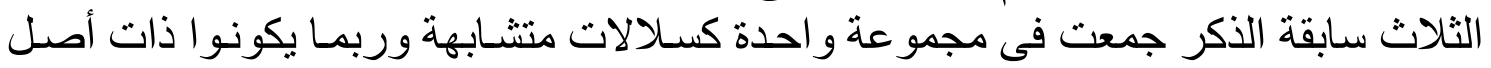

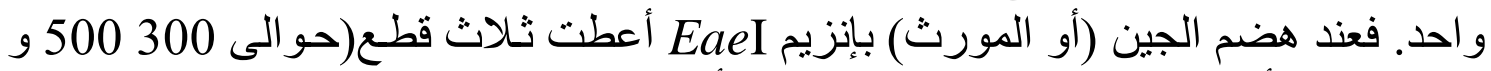

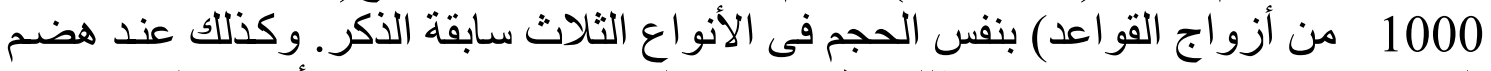
المورث بإنزيم EcoRI نتج عن ذللك قطعتين (حو الى 250 و 1550 من أزواج القو القو اعد) مع

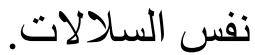

إن سلالاتى الأرجاس بيربيكاس و الأرجاس هيرمانسى ربما تكونـا منشـابهتان ور اثيا

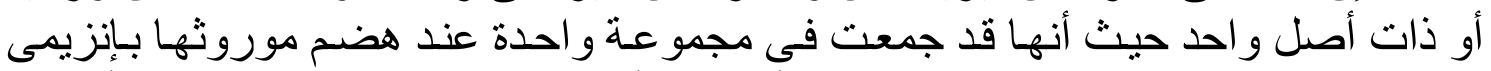

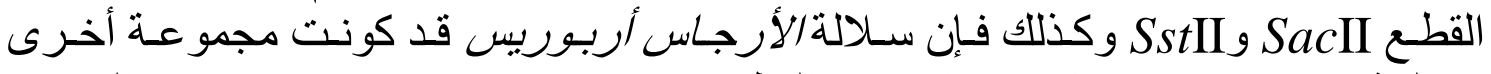

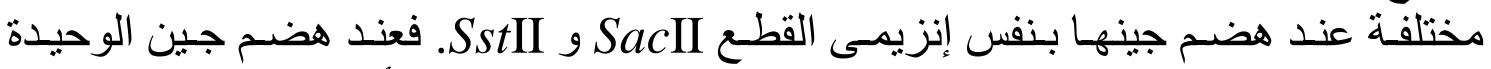

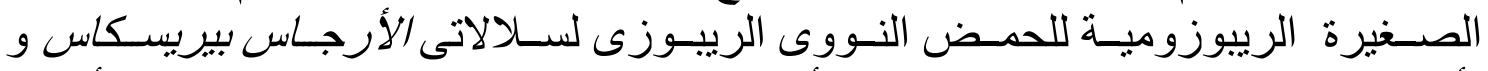

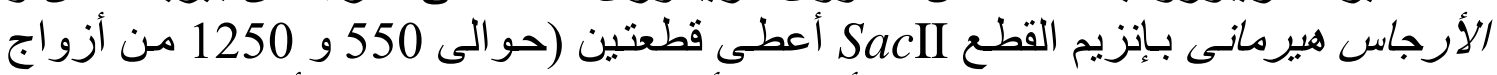

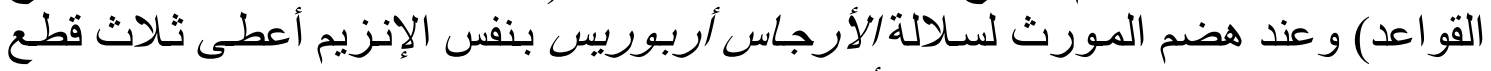

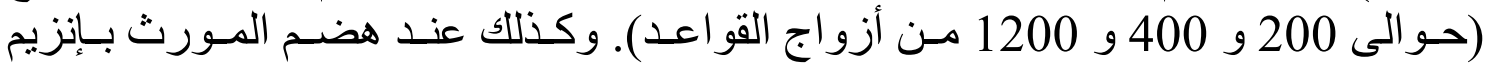


EcoRI

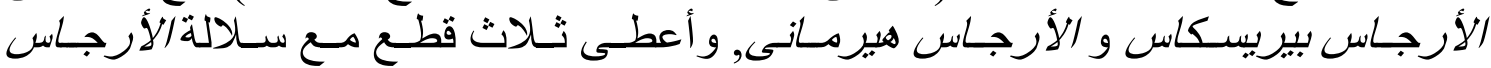

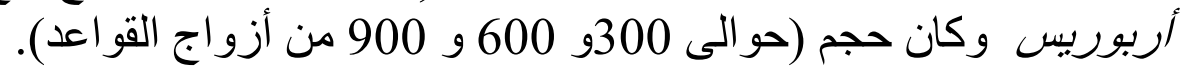

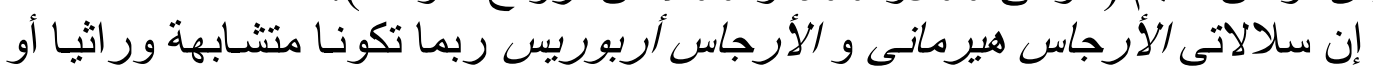

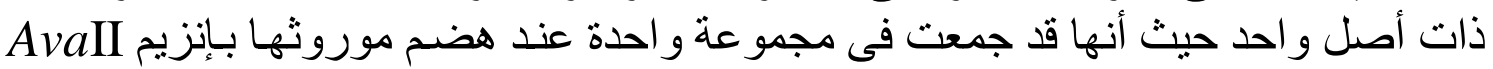

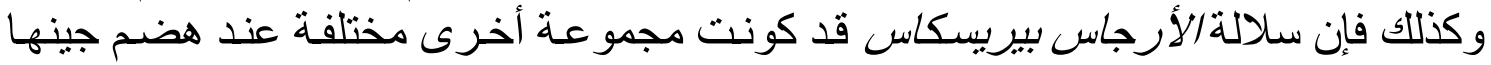

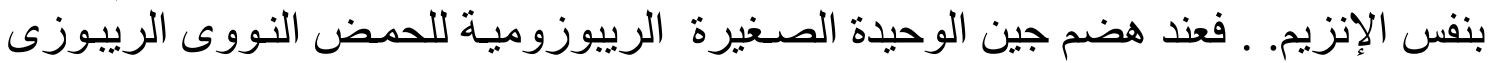

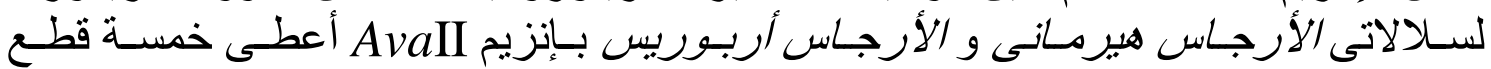

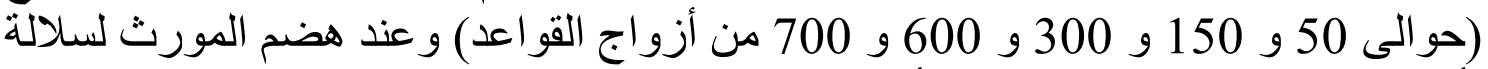
الأرجاس بيريسكاس بنفس الإنزيم أعطى خمسة قطع ولكن ألك لهم حجم مختلف (حو الى الى 1500 و و

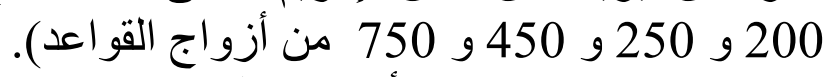

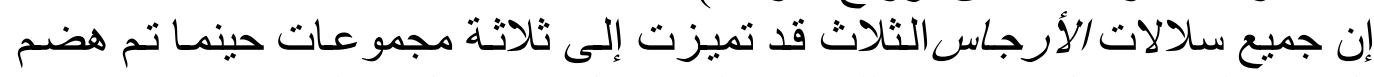

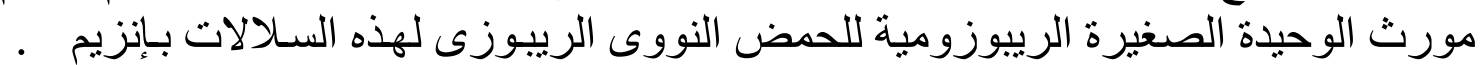
EvaI

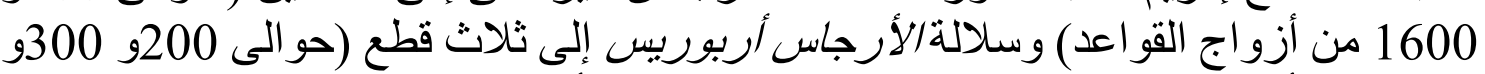

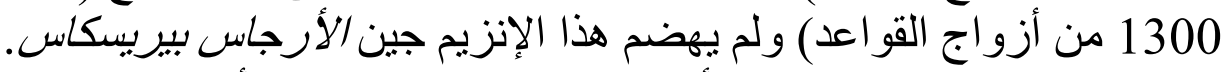

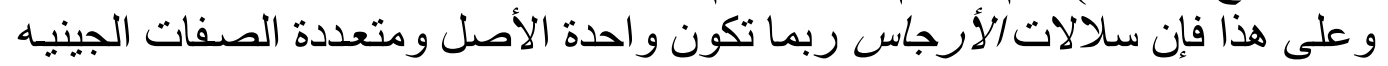

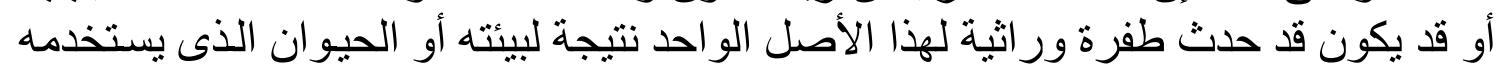

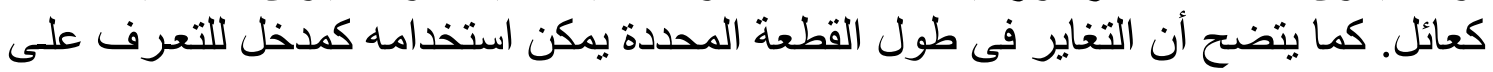

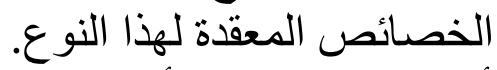

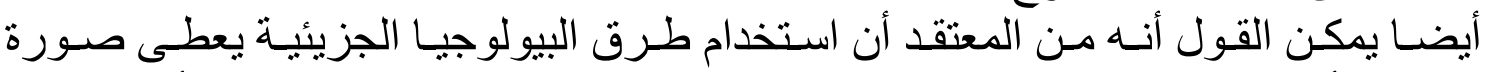

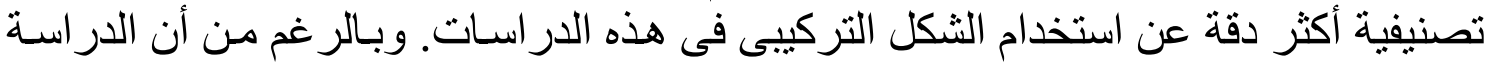

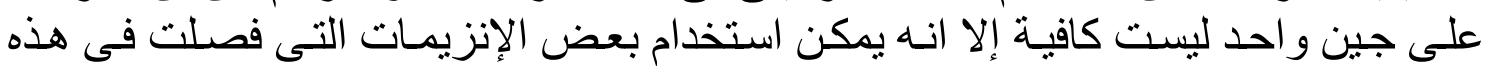
الدر اسة للعمل كمجسات للتعرف على سلالات الأرجاس. 